(c) 2009 Plant Management Network.

Accepted for publication 9 April 2009. Published 12 May 2009.

\title{
Evaluation of Foliar Sprays of Bacteriophages for the Management of Bacterial Canker in Greenhouse Tomatoes
}

\author{
David M. Ingram, Central Mississippi Research \& Extension Center, \\ Mississippi State University, 1320 Seven Springs Road, Raymond, MS \\ 39154; and Shi-En Lu, Department of Entomology and Plant \\ Pathology, Mississippi State University, Mississippi State, MS, 39762 \\ Corresponding author: David M. Ingram. davidi@ext.msstate.edu
}

Ingram, D.M., and Lu, S.-E. 2009. Evaluation of foliar sprays of bacteriophages for the management of bacterial canker in greenhouse tomatoes. Online. Plant Health Progress doi: 10.1094/PHP-2009-0512-01-RS.

\begin{abstract}
AgriPhage applied as a preventative foliar spray significantly reduced severity of bacterial canker of greenhouse tomato in two of three years. Area under the disease progress curves (AUDPC) indicated that AgriPhage slowed the progression of bacterial canker symptom development by $50 \%$ and $59 \%$ in 2006 and 2007 , respectively. Plant mortality was significantly reduced by $76 \%$ in 2006 as compared to the inoculated control. AgriPhage-treated plants produced significantly greater total yield in 2006 only. Copper and Kasumin sprays also significantly reduced severity (AUDPC) of bacterial canker in 2007 as compared to the inoculated control. However, none of these treatments reduced symptom development or increased yield in 2008.

I ntroduction

Greenhouse tomato production occurs on approximately 850 acres in the United States (4). The value of the crop is estimated to be approximately $\$ 340$ million dollars annually. Bacterial canker, caused by Clavibacter michiganensis subsp. michiganensis ( $\mathrm{Cmm})$, is a very destructive disease of tomato, both in field and greenhouse production systems $(11,12)$. The bacterium overwinters on plant debris and weed hosts, and it can be seed-borne. The disease is spread from plant to plant by splashing water, contaminated equipment, or workers' hands.

Symptoms of bacterial canker in greenhouse tomatoes differ from those expressed in the field. The disease is usually first observed on plants when the first fruit cluster begins to ripen. The initial symptom is the appearance of small, water-soaked areas between veins on leaves in the upper one-third of the plant (Fig. 1). These are characteristic symptoms of localized infection (7). The watersoaked lesions enlarge quickly and become tan and necrotic. Eventually the necrotic area advances to a more dark brown coloration (Fig. 1). As the disease progresses, entire leaves become necrotic and remain attached to the plant. Following significant interveinal leaf necrosis, systemic infection occurs that results in a general wilting from the top of the plant that progresses downward. Wilted plants exhibit vascular discoloration (Fig. 2) and usually die rapidly. Stems of dying plants develop dark brown cankers at the nodes and some of these cankers split open as the plant dries down. Fruit symptoms have not been observed in greenhouse tomatoes (D. M. Ingram, personal observation).
\end{abstract}



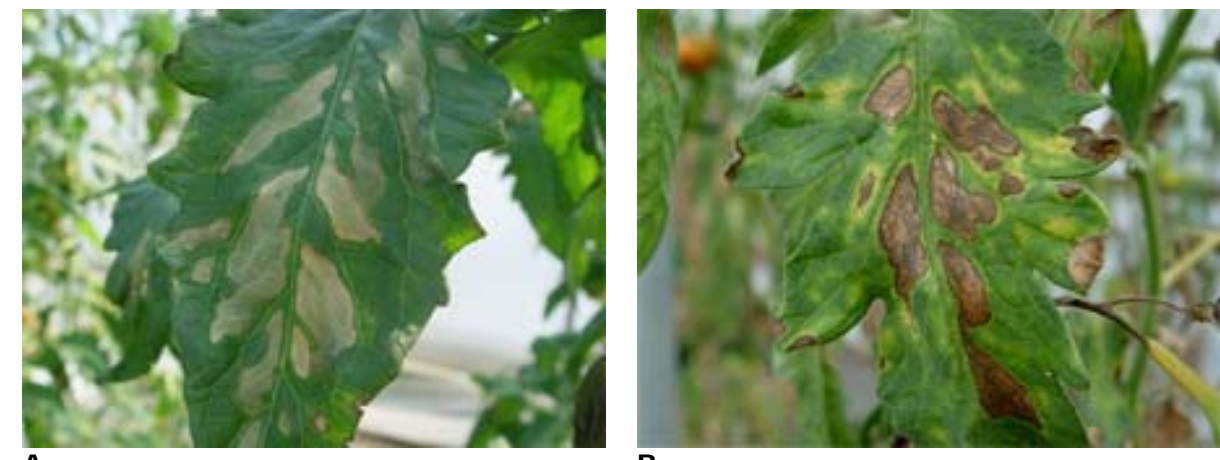

Fig. 1. Initial (A) and advanced (B) symptoms of bacterial canker on leaves of greenhouse tomato.

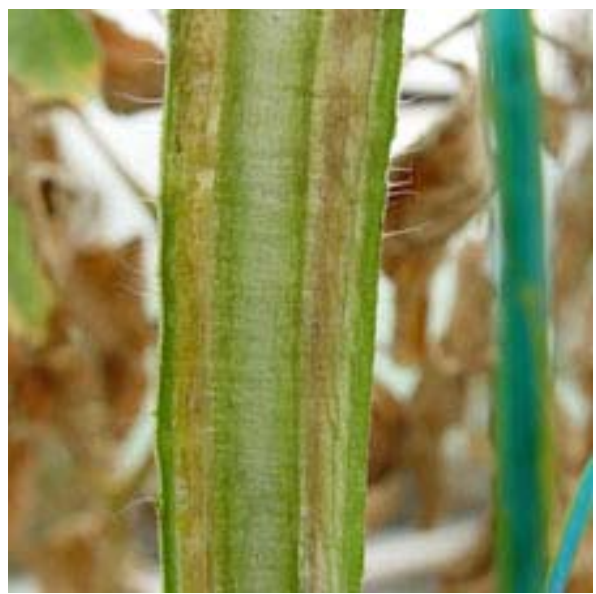

Fig. 2. Vascular discoloration caused by bacterial canker of greenhouse tomato.

Bacterial canker of tomato has recently become the most important disease in the greenhouse tomato industry, particularly in the western United States, Mexico, and Canada (M. Bledsoe and K. Tifft, personal communication). At the first sign of symptom development, plants are removed from the greenhouse. Removal of large numbers of plants results in devastating economic losses ranging in the millions of dollars. Entire greenhouses have been destroyed by the disease (M. Bledsoe, personal communication). It is thought that infected transplants were the initial source of inoculum introduction (7). Another hypothesis put forth to explain recurrence of the disease in a greenhouse was that the bacteria survived in plant debris resulting from the cultural practices of leaf and cluster pruning which left large amounts of plant residue on the greenhouse floor during much of the growing season.

Management of bacterial canker begins with clean seeds and healthy transplants. Seeds can be disinfested by treating with calcium hypochlorite, hydrochloric acid, or soaking in hot water (7). Copper bactericides are labeled for bacterial speck and spot on field tomatoes and other crops but efficacy against bacterial canker in greenhouse tomato culture is unknown. Many products have been tested for efficacy against bacterial canker including the compounds inducing systemic acquired resistance $(13,16)$, antibiotics $(17)$, fluorescent pseudomonads (3), plant growth promoting rhizobacteria (6), composts (18), and various combinations of products with copper (9).

Recently, specific bacteriophages for the control of bacterial spot in field grown tomato have been commercially developed (OmniLytics Inc., Salt Lake City, UT). A bacteriophage is a virus that is pathogenic to a bacterium and results in lysis of the bacterial cells (1). Bacteriophages have been shown to suppress bacterial spot in tomato (13). However, research is needed on how to best use bacteriophages in a greenhouse environment. Research has been conducted on improving the efficacy of bacteriophages applied in the field using various formulations with natural products such as skim milk (2). Findings have 
suggested that bacteriophage products perform best when applied at dusk, due to the photosensitivity of the phage (2). Recently, Cmm-specific bacteriophages have been developed by OmniLytics and EPA registration is pending further efficacy trials. The objective of this study was to evaluate foliar sprays of bacteriophages for efficacy against bacterial canker in greenhouse tomato.

\section{Bacteriophage Efficacy Trials}

Clavibacter michiganensis subsp. michiganensis (Lu-01) isolated from symptomatic tomato plants at Village Farms Greenhouses in Marfa, TX, was used for this study. The isolate was maintained in $10 \%$ glycerol at $-80^{\circ} \mathrm{C}$ and recovered by culturing on nutrient broth yeast extract (NBY) agar (8). To prepare inoculum, bacterial cells growing on NBY plates for $24 \mathrm{~h}$ were harvested and suspended in sterile $0.02-\mathrm{M}$ phosphate buffer ( $\mathrm{pH}$ 7.0). The bacterial cell concentration was adjusted to approximately $1 \times 10^{8} \mathrm{CFU} / \mathrm{ml}\left(\right.$ O.D. 0.3 at $\mathrm{A}_{420}$ ) using a spectrophotometer. Upon termination of each trial in each year, symptomatic plant tissue plated onto NBY resulted in bacterial colonies typical of Clavibacter michiganensis subsp. michiganensis and identity was confirmed with PCR using the species-specific primers CMM5 and CMM6 (5). Additionally, the presence of $\mathrm{Cmm}$ in symptomatic plants was confirmed by testing with Agdia immunostrips.

Greenhouses at Truck Crops Branch Experiment Station in Crystal Springs, MS, were used for all experiments. Plots (rows) were arranged in a randomized complete block design with four replications each with twelve plants. Plants were grown in perlite contained in upright, 7-gal plastic bags in 2006 or rockwool slabs (Grodan Inc., Coppell, TX) during 2007-2008 and fertigated with a solution of water and fertilizer [Total Gro (3-13-29), Winnsboro, LA, and calcium nitrate] six times per day for seven minutes at each watering. Plants were grown according to standard greenhouse tomato production guidelines (14).

Each replicate consisted of six grafted plants (rootstock cv. 'Maxifort'; scion cvs. 'Clarance' in 2006, 'Bizarr' in 2007, and 'Success' in 2008) each with two terminals, which resulted in 12 plants per replication. Each of these cultivars has been grown in commercial greenhouses in the USA. It is common in today's greenhouse tomato production system to change cultivars from one year to the next. Each cultivar has been observed to be highly susceptible to $\mathrm{Cmm}$ in a commercial greenhouse environment (Karin Tifft, personal communication).

In each year, control products were applied as preventative foliar sprays beginning just after transplanting. Prior to inoculation, foliar applications were made five times in 2006 and four times in 2007 and 2008 (Table 1). On the day of inoculation, plants were treated with control products one hour prior to inoculation. Plants were then inoculated by either wounding the stem with a syringe and depositing a drop of bacterial suspension on the juncture of a leaf petiole and the stem (2006), removing one mature leaf and spraying the leaf scar and the entire plant (2007), or spraying bacterial suspension over all foliage until just before runoff (2008). A non-inoculated control was not included in these trials in 2007 and 2008 because of the spray inoculation method and the resulting likelihood of $\mathrm{Cmm}$ infection in non-inoculated plots placed randomly among inoculated plots in the greenhouse environment. 
Table 1. Application rates and times for products evaluated for the control of bacterial canker in greenhouse tomatoes, Crystal Springs, MS, 2006 to 2008.

\begin{tabular}{|c|c|c|c|c|c|}
\hline \multirow[b]{2}{*}{ Treatment } & \multirow[b]{2}{*}{ Rate } & \multicolumn{3}{|c|}{ Applications } & \multirow[b]{2}{*}{ Source } \\
\hline & & $2006^{w}$ & $2007^{x}$ & $2008^{y}$ & \\
\hline $\begin{array}{l}\text { Inoculated } \\
\text { control }^{z}\end{array}$ & - & $x$ & $x$ & $x$ & - \\
\hline $\begin{array}{l}\text { Bacterio- } \\
\text { phage }\end{array}$ & $\begin{array}{l}\text { 1: } 10 \mathrm{v} / \mathrm{v} \text { solution } \\
\text { (Agriphage: water) }\end{array}$ & $x$ & $x$ & $x$ & $\begin{array}{l}\text { AgriPhage, } \\
\text { OmniLytics Inc, } \\
\text { Salt Lake City, UT }\end{array}$ \\
\hline Kasugamycin & 100 ppm & & $x$ & $x$ & $\begin{array}{l}\text { Kasumin, Arysta Life } \\
\text { Sciences, Cary, NC }\end{array}$ \\
\hline $\begin{array}{l}\text { Copper } \\
\text { oxychloride } \\
+ \text { Copper } \\
\text { hydroxide }\end{array}$ & $3.0 \mathrm{pt} / \mathrm{acre}$ & & $x$ & $x$ & $\begin{array}{l}\text { Badge, } \\
\text { Isagro USA Inc., } \\
\text { Morrisville, NC }\end{array}$ \\
\hline
\end{tabular}

w Treatments applied February 7, 14, 22, 28; March 3, 7, 10, 15, 23, 29; and April 7, 12, and 25.

$x$ Treatments applied January 25, 31; February 2, 7, 14, 21; and March 2, 14, and 21.

y Treatments applied January 30; February 6, 12, 21, 28; and March 5.

${ }^{z}$ All plants inoculated with $1 \times 10^{8} \mathrm{CFU} / \mathrm{ml}$ on March 3, February 7, and February 21 in 2006, 2007, and 2008, respectively.

Data collected included the degree of interveinal leaf necrosis expressed as a percentage of total leaf area, area under the disease progress curve (AUDPC), and number of dead plants. Interveinal leaf necrosis was visually estimated using a modification of J ames' manual of assessment keys for plant diseases (10) and was expressed as percentage (ranging from $0=$ no leaf necrosis to $100=$ all plant leaves necrotic) of leaf area exhibiting necrotic tissue. Visual ratings were made seven times in 2006, and six times in 2007 and 2008 (Table 2).

Marketable, cull, and total fruit yield were also determined. AUDPC was calculated for interveinal leaf necrosis by using the formula of Shaner and Finney (15). All data were subjected to analysis of variance using SAS version 9.1.2 for PC (SAS Institute Inc., Cary, NC). Fisher's Protected Least Significant Difference Test $(\mathrm{P}=0.05)$ was used to separate means.

\section{Effect of Bacteriophage on Bacterial Canker in 2006}

The first symptoms of interveinal leaf necrosis were observed 12 days postinoculation and the first dead plants were observed 45 days post-inoculation. Final interveinal leaf necrosis ranged from $71 \%$ in the inoculated control to $46 \%$ for the AgriPhage-treated plants (Table 2). No bacterial canker symptoms were observed in the non-inoculated control. Plant mortality followed the same pattern as leaf necrosis. Numbers of dead plants ranged from $95 \%$ in the inoculated control to $22.5 \%$ in the AgriPhage treatment. Area under the disease progress curve was significantly reduced by $50 \%$ with foliar applications of AgriPhage (Table 2).

The AgriPhage treatment resulted in significantly greater cull fruit weight (30.0 lb/ plot) as compared to the inoculated control (23.0 lb/ plot) and the noninoculated control (16.3 lb/ plot). The non-inoculated control produced the greatest marketable fruit weight (48.9 lb/ plot), which was significantly greater than the inoculated control $(32.1 \mathrm{lb} / \mathrm{plot})$ and the AgriPhage treatment (33.0 lb/ plot). The non-inoculated control (65.2 lb/ plot) and the AgriPhage $(63.9 \mathrm{lb} /$ plot) treatment resulted in significantly greater total fruit yield as compared to the inoculated control (55.1lb/ plot). 
Table 2. Influence of control products on severity of bacterial canker in greenhouse tomatoes, Crystal Springs, MS, 2006 to 2008.

\begin{tabular}{|l|l|c|c|c|}
\hline \multirow{4}{*}{ Year } & Treatment $^{\mathrm{v}}$ & $\begin{array}{c}\text { Interveinal } \\
\text { Ieaf necrosis } \\
(\%)^{\mathrm{w}}\end{array}$ & $\begin{array}{c}\text { Plant } \\
\text { mortality } \\
(\%)^{\mathrm{x}}\end{array}$ & AUDPC $^{\mathrm{y}}$ \\
\hline \multirow{3}{*}{2006} & Non-inoculated control & $0^{\mathrm{z}} \mathrm{c}$ & $0 \mathrm{c}$ & $0 \mathrm{c}$ \\
\cline { 2 - 5 } & Inoculated control & $71.3 \mathrm{a}$ & $95.0 \mathrm{a}$ & $1706 \mathrm{a}$ \\
\cline { 2 - 5 } & AgriPhage & $46.3 \mathrm{~b}$ & $22.5 \mathrm{~b}$ & $853 \mathrm{~b}$ \\
\hline \multirow{2}{*}{2007} & Inoculated control & $71.3 \mathrm{a}$ & $71.3 \mathrm{a}$ & $1299 \mathrm{a}$ \\
\cline { 2 - 5 } & AgriPhage & $56.3 \mathrm{~b}$ & $17.5 \mathrm{a}$ & $767 \mathrm{c}$ \\
\cline { 2 - 5 } & Kasumin & $68.8 \mathrm{a}$ & $48.5 \mathrm{a}$ & $1045 \mathrm{~b}$ \\
\cline { 2 - 5 } & Badge & $65.0 \mathrm{a}$ & $52.0 \mathrm{a}$ & $1072 \mathrm{~b}$ \\
\cline { 2 - 5 } & Inoculated control & $71.3 \mathrm{a}$ & $87.3 \mathrm{a}$ & $1264 \mathrm{a}$ \\
\cline { 2 - 5 } & AgriPhage & $62.5 \mathrm{a}$ & $63.8 \mathrm{a}$ & $1031 \mathrm{a}$ \\
\cline { 2 - 5 } & Kasumin & $71.3 \mathrm{a}$ & $80.2 \mathrm{a}$ & $1066 \mathrm{a}$ \\
\cline { 2 - 5 } & Badge & $63.8 \mathrm{a}$ & $68.2 \mathrm{a}$ & $1048 \mathrm{a}$ \\
\hline
\end{tabular}

$\checkmark$ See Table 1 for application rates and schedules.

w Plants in a plot were visually rated for percentages of tissues that exhibited interveinal necrosis. $0=$ no symptoms and $100=$ entire plant symptomatic. Visual rating data collected on March 23, 29, April 7, 12, 25, May 2, 10 in 2006; March 2, 7, 14, 21, 27, April 3, in 2007; and March 10, 17, 24, 31, April 7 and April 11 in 2008. Data presented are from the final rating at the termination of the trial.

$x$ Values represent the average percentage of plants killed by bacterial canker.

${ }^{y}$ AUDPC (area under the disease progress curve) for interveinal necrosis calculated using the formula of Shaner and Finney (15).

z For each year, means in a column followed by the same letter are not significantly different according to Fisher's Protected Least Significance Difference Test $(P=0.05)$.

\section{Effect of Control Products on Bacterial Canker in 2007}

Interveinal leaf necrosis symptoms were significantly reduced (21\%) by AgriPhage applied as a foliar spray, but Kasumin and Badge did not significantly reduce symptoms (Table 2). The amount of leaf area affected ranged from 56\% for the AgriPhage-treated plants to $71 \%$ for the inoculated control. Plant mortality was reduced by treatment with AgriPhage, although not statistically significant due to variability among plots. Percentage of dead plants ranged from $17 \%$ for the AgriPhage treatment to $71 \%$ for the inoculated control. Kasumin and Badge each resulted in significantly lower AUDPC. AgriPhage reduced symptom development (AUDPC) by 59\% compared to the inoculated control. There were no differences among treatments for cull fruit weight, marketable fruit weight and total yield (data not shown).

\section{Effect of Control Products on Bacterial Canker in 2008}

AgriPhage, Kasumin and Badge were tested again in 2008. None of the products tested influenced severity of bacterial canker, plant mortality, or AUDPC (Table 2), and no product influenced cull fruit weight, marketable fruit weight and total yield (data not shown).

\section{Summary}

No chemical or biological control products have previously been shown to reduce development of bacterial canker in greenhouse tomatoes. These studies show that preventive foliar applications of bacteriophage (AgriPhage) significantly reduced symptom development (AUDPC) of bacterial canker in greenhouse tomato in two of three years. AgriPhage also increased total fruit yield in one of three years. The lack of a yield benefit observed in these trials is due to the conduct of the experiments. Infected plants were left in the trials until maximum plant mortality was observed. Fruit symptoms were not observed 
and fruit ripened normally and were harvested from severely wilted plants. This differs from the real-life greenhouse situation where infected plants are removed immediately, thus resulting in significantly lower yield across the greenhouse. The antibiotic treatment (Kasumin) and the copper-containing product (Badge) were slightly effective in reducing disease severity in one of two years.

There were variations in experimental procedures used in each of the three years. Although the inoculation method used differed in each year, disease development was observed to be identical, with interveinal leaf necrosis reaching $71 \%$ in the inoculated control by the end of the trials. Symptoms developed within 12 to 20 days of inoculation in each year resulting in similar AUDPC values. The different cultivars used in each year exhibited identical symptom expression and similar disease development. The number of applications of the control products also varied among years, ranging from 13 times in 2006, 8 times in 2007 and 6 times in 2008. The reduction in the number of applications may explain the lack of efficacy of the control products in 2008. However, it seems unlikely that growers would make more than 6 to 8 applications of bacteriophages in a single growing season, due to labor and economic constraints. The interval of time between applications may have also influenced efficacy. Improvement in the timing of applications may prove beneficial for demonstrating consistent efficacy among control products. Nevertheless, the bacteriophages showed a potential to suppress bacterial canker of tomato in greenhouse conditions, and appears to be comparable to other products tested thus far.

More research is needed to understand how to best utilize bacteriophages for managing bacterial canker in a greenhouse environment. Future research involving rates of products, timing and number of applications, and application method (spray versus fogging) may provide more consistent reduction in disease severity, resulting in improved management of bacterial canker of greenhouse tomato.

\section{Literature Cited}

1. Agrios, G. N. 2005. Plant Pathology. Academic Press, New York, NY.

2. Balogh, B., J ones, J. B., Momol, M. T., Olson, S. M., Obradovic, A., King, P., and J ackson, L. E. 2003. Improved efficacy of newly formulated bacteriophages for management of bacterial spot on tomato. Plant Dis. 87:949-954.

3. Boudyach, E. H., Fatmi, M., Boubaker, H., Ait Ben Aoumar, A., and Akhayat, O. 2004. Effectiveness of fluorescent pseudomonads strains HF 22 and HF142 to control bacterial canker of tomato. J. Food Agr. Environ. 2:115-120.

4. Cook, R., and Calvin, L. 2005. Greenhouse tomatoes change the dynamics of the North American fresh tomato industry. Rep. no. 2. April 2005. USDA-Economic Research Service, Washington, DC.

5. Dreier, J., Bermpohl, A., and Eichenlaub, R. 1995. Southern hybridization and PCR for specific detection of phytopathogenic Clavibacter michiganensis subsp. michiganensis. Phytopathology 85:462-468.

6. Girish, N., and Umesha, S. 2005. Effect of plant growth promoting rhizobacteria on bacterial canker of tomato. Archives of Phytopathol. Plant Prot. 38:235-243.

7. Gleason, M. L., Gitaitis, R. D., and Ricker, M. D. 1993. Recent progress in understanding and controlling bacterial canker of tomato in eastern North America. Plant Dis. 77:1069-1076.

8. Gross, D. C., and DeVay, J. E. 1977. Production and purification of syringomycin, a phytotoxin produced by Pseudomonas syringae. Phytopathol. Plant Prot. 11:1328.

9. Hausbeck, M. K., Bell, J., Medina-Mora, C., Podolsky, R., and Fulbright, D. W. 2000. Effect of bactericides on population sizes and spread of Clavibacter michiganensis subsp. michiganensis on tomatoes in the greenhouse and on disease development and crop yield in the field. Phytopathology 90:38-44.

10. J ames, C. 1971. A manual of assessment keys for plant diseases. Publication No. 1458. Canada Dept. of Agr., Ottawa, Canada.

11. J ones, J. B., J ones, J. P., Stall, R. E., and Zitter, T. A. 1991. Compendium of Tomato Diseases. American Phytopathological Society Press, St. Paul, MN.

12. Koike, S. T., Gladders, P., and Paulus, A. O. 2007. Vegetable Diseases: A Color Handbook. Academic Press, San Diego, CA. 
13. Obradovic, A., J ones, J. B., Momol, M. T., Balogh, B., and Olson, S. M. 2004. Management of tomato bacterial spot in the field by foliar applications of bacteriophages and SAR inducers. Plant Dis. 88:736-740.

14. Snyder, R. G. 2001. Greenhouse tomato hand book. Ext. Serv. Publ. 121828. Mississippi State Univ., Crystal Springs, MS.

15. Shaner, E., and Finney, R. E. 1977. The effect of nitrogen fertilization on the expression of slow-mildewing resistance in Knox wheat. Phytopathology 67:10511056.

16. Soylu, S., Baysal, O., and Soylu, E. M. 2003. Induction of disease resistance by the plant activator, acibenzolar-S-methyl (ASM), against bacterial canker (Clavibacter michiganensis subsp. michiganensis) in tomato seedlings. Plant Sci. 165:10691075.

17. Theodoro, G. de F., and Maringoni, A. C. 2000. In vitro and in vivo action of chemicals on Clavibacter michiganensis subsp. michiganensis, causal agent of the bacterial canker of tomato. Sci. Agr. 57:439-443.

18. Yogev, A., Raviv, M., Kritzman, G., Hadar, Y., Cohen, R., Kirshner, B., and Katan, J . 2008. Suppression of bacterial canker of tomato by composts. Crop Prot. 28:97103. 